\title{
Legal Protection analysis trough Children's Labor in Indonesia
}

\section{Herlina Panggabean}

Dosen Fakulltas Hukum Universitas Sisingamangaraja XII Tapanuli, Indonesia

E-mail: linagabe53@gmail.com

\begin{abstract}
This study aims to find out the rules of laws on children Labors, laws protection on children in Indonesia labors, and what obstacles the realization and existence of laws protection on children labors.The findings of this study are expected to improve the knowledge of law, and specifically to be useful as a reference in comprehending the knowledge of regulations, and obstacles of laws protection on children labors in Indonesia, besides, the finding of this research are also expected to be useful as a reference for further other researches, and as a base alternative for government or lawyers in straightening up laws related to children as labors in Indonesia. The findings of this study are also expected to be published that the society gets the information in regulations, obstacles of laws on children labors. The research method of data collection was Library Research which; bases, conceptions, point of views, doctrines are derived in two main ways the references (general, and specific), as a first general point of references are lagislation, regulations, text books, and dictionaries, and as the second spesific references are journals, research reports, etc.
\end{abstract}

Keywords -Children Protection, Labors.

\section{INTRODUCTION}

Children are the generations of the nation and when it comes to replacing the older in continuing the wheel of the nation's life, thus, children need to be nurtured well so they are not wrong in their lives. Every component of the nation, both the government has a serious obligation to pay attention the growth and development of children. The components must provide children guidance are parents, family, community and government. Today, we often encounter the number of child laborers amidst the 12-year compulsory education conditions have been declared by the government. The midst of government's intensive efforts to ask children school for 12 years, it has been "tainted" by a large number of child workers who cannot participate in school. This is due by economic limitations or the economic crush experienced and lack of parental responsibility so that "handing" their children to take responsibility of money, children become workers rather than becoming school students. Children must be protected so they do not become victims of anyone's actions (individuals or groups, private or government organizations), directly or indirectly. What is meant by victims are those who suffer losses (mental, physical, social), due to passive actions, or active actions of other people or groups (private or government). Basically, children cannot protect themselves from various actions that cause mental, physical, social damage in various fields of life and livelihoods. Children must be assisted by others. From the description above, the problems that will be examined in this study are: a) regulations on legal protection for children in Indonesia; b) legal protection of children as workers; c) obstacles in the realization of legal protection for children as workers.

\section{REVIEW OF LITERATURE}

\section{Children's Rights}

United Nations General Assembly (UN) adopted the Declaration on the Rights of the Child. In the Preamble of this Declaration, it is implied that humanity is obliged to provide the best for children. This declaration contains 10 (ten) principles regarding children's rights, namely: 1) The child has the right to enjoy all his rights in accordance with the provisions contained in this declaration; 2) Children are entitled to special protection and must have opportunities guaranteed by law and other means; 3) children birth are entitled names and nationalities; 4) children have the right and must be guaranteed socially for healthy growth and development; 5) children who are physically, mentally disabled and have a weak social position due to certain conditions must receive education, care and special treatment; 6) the child's personality grows optimally and 
harmoniously, They needs affection and understanding; 7) Children are entitled to a compulsory education for free at the elementary school level; 8) the child must take precedence in receiving protection and assistance; 9) children must be protected from all forms of neglect, violence, exploitation, they must not be subject to trafficking; 10) children must be protected from acts that lead to forms of social discrimination, religion or other forms of discrimination.

\section{Principles of Child Protection}

Child protection is effort to create conditions so that every Children can exercise his rights and obligations for the proper development and growth of the child physically, mentally and socially. Child protection is an embodiment of justice in a society, thus child protection is sought in various fields of state and community life. Child protection activities bring legal consequences, both relation in law and unwritten law. Child protection is related to several things that need attention, namely: 1) broad scope of protection: a) the main protection includes, among others, clothing, food, settlement, education, health, law; b) includes physical and spiritual things; c) also concerning the classification of primary and secondary needs which results in priority fulfillment. 2) Guarantees for the implementation of protection: a) appropriately to achieve maximum results there needs to be a guarantee for the implementation of these protection activities; b) this guarantee should be stated in the form of a law or regional regulation; c) arrangements must be adjusted to the conditions and situation in Indonesia without ignoring the means of protection carried out in other countries.

\section{The parties responsible for child protection}

Child protection is sought by everyone, parents, family, community, government and country. Article 20 of Law No. 23 in 2002 determines: The state, government, community, family and parents are obliged and responsible for the organization of child protection. The obligations and responsibilities of the government efforts to protect children are regulated in Law No. 23 in 2002, namely: a) respecting and guaranteeing the rights of every child regardless of ethnicity, religion, race, class, gender, ethnicity, culture and language; b) provide support facilities and infrastructure in implementation of child protection; c) Ensure the protection, care and welfare of children by taking into account the rights and obligations of parents, guardians or other people who are generally responsible for the child; d) guaranteeing children to exercise their right to express their opinions in accordance with the age and intelligence level of children. The obligations and responsibilities of family and parents in child protection efforts are regulated in Article 26 of Law no. 23 in 2002, namely: a) Caring for, educating and protecting children; b) grow and develop children according to their abilities, talents and interests; c) prevent marriages at the age of children. The government, family and parents are obliged to protect children from the actions of: a) harvesting of the child's organs or children's tissues without regard to the child's health; b) buying and selling child organs. c) health research that uses children as objects of research without parental consent and does not prioritize the best interests of the child.

\section{RESEARCH METHODOLOGY}

The research method applied in this study uses library research in the form of scientific books. For the success of a good research in providing an overview and answers to the issues raised, the objectives of research determined by the method used in the study. Can be quoted Soerjono Soekanto's opinion regarding legal research, as follows: Legal research is basically a scientific activity that is based on certain methods, systematic and thinking that aims to study one or several specific legal phenomena by analyzing it.

\section{FINDING AND DISCUSSION}

The law governing child labor is Law No. 13 in 2003 concerning employment. This law regulates matters relating to child labor ranging from the age limit which work is permitted, who is classified as child, remuneration and protection for child labor. Childhood is a time of free play and humor and the opportunity to learn as much as possible. In the context of a child's development when he is involved in a game, this is not just playing but actually a child can learn to be smart in various ways. Parents can encourage their children to work because of the strong assumption in our society that the child is a family asset so that everything related to the child becomes a personal matter of the parents or in other words the parent has the full right to the child. Encouragement of children to work is increasingly strengthened by the lack of access to education for them. It is not only a matter of cost, but also the mental, intellectual and physical conditions that a child needs to be able understand the lessons given at school. What is meant by the worst forms of child labor are: a) All forms of slavery, such as the sale and trafficking of children to pay debts and forced labor. Including coercion of children to engage in weapons dispute activities; b) The purchase and offer of children for prostitution and pornography activities; c) The purchase and offer of children for illegal activities, especially trafficking, 
narcotics and illegal drugs; d) Work which naturally or in conditions endanger health, safety and morals. Preventive legal protection is carried out as a preventive measure that can be pursued by limiting the types of work may not be carried out by child labor by establishing certain conditions for employers or companies that have child labor. This can be seen on Article 69, Article 72, Article 73, and Article 74 of Law Number 13 in 2003 concerning Manpower. The repressive legal protection can be pursued not only involving employers and child labor but must also be based on the corridor of Law Number 35 in 2014 concerning Child Protection. The types of work that endanger the health, safety or morals of children are determined by Ministerial Decree No: Kep. 235 / Men / 2003, namely: 1) Types of work that endanger work health and safety: a) work related to machinery, aircraft, installations and other equipment; b) Work performed in a hazardous work environment includes work that contains physical hazards. Jobs that contain chemical hazards. Occupations that contain biological hazards; c) work that contains certain characteristics and conditions and hazardous conditions: bridge construction, buildings, irrigation / roads. 2) Types of work that endanger the moral of children. Work in bars, discotheques, karaoke, poke balls, cinemas, massage parlors or locations that can be used as prostitution. Work as a model for the promotion of liquor, sexually stimulating drugs and / or cigarettes.

\section{Protection of Child Labor}

Child labor is a term for employing small children. The term child labor have the connotation of exploiting young children for their labor, with a small salary or consideration for the development their personality, safety, health, and future prospects. In some countries, this is considered bad if a child is under a certain age, not including domestic work and school work. No one is allowed to employ children in all types of industries. This is clearly regulated in the regulation of employing children, children aged 13 years or older may be employed in non-industrial companies. However, children from this category, who have not completed form III of secondary school, are prohibited from entering and being employed in any public entertainment venue except for the purpose making a profit. A child who works in any workplace, whether with a salary or not, meet all the rules for employing children. Work rules for children do not apply to children who are registered as apprentices / registered as students with certain skills under the law (Article 47). Employ children who are 13 years old and have completed Form III (Senior High School) children who are 13 years old but under 15 years old, and have completed form III can be employed in non-industrial companies by complying the following conditions: a) the parents concerned must submit proof that their child has completed form III (Senior High School) the prospective employer; b) written permission from parents; c) cannot be employed: before 7 am or after 7 pm; more than 8 hours a day; work continuously more than 5 hours without breaks or rest periods of less than 1 hour. Carry items that weigh more than $18 \mathrm{~kg}$.

\section{The Legal Barriers protection of children as workers}

a. Indonesian Child Protection Commission

In order to increase the effectiveness of the implementation of child protection, with this law an independent Indonesian Child Protection Commission was formed. In Article 75 as follows: (1) Membership of the Indonesian Child Protection Commission consists of 1 (one) chairman, 2 (two) deputy chairs, 1 (One) secretary and 5 (five) members; (2) The membership of the Commission as referred to in paragraph (1) consists of elements of the government, religious leaders, community leaders, social organizations, professional organizations, non-governmental organizations, businesses, and community groups who are concerned with child protection; (3) The membership of the Commission as referred to in paragraph (1) and paragraph (2) shall be appointed and dismissed by the president after receiving the consideration of the House of Representatives of the Republic of Indonesia, for a term of 3 (three) years, and may be reappointed for 1 (one) time length of service; (4) Further provisions regarding the completeness of the organization, work mechanism, and financing are stipulated by a Presidential Decree. Criminal provisions for the protection of Indonesian children in accordance with Article 77, every person who intentionally acts: a) Discrimination against children which causes children to suffer losses, both material and moral, inhibits their social functioning or; b) Neglect of children which results in the child experiencing illness or suffering both physically, mentally and socially; c) sentenced to a maximum imprisonment of 5 (five) years or a maximum fine of Rp. 100,000,000 (one hundred million rupiah).

\section{b. Government Constraints in Tackling the Exploitation of Child Labor.}

The system is a unit consisting of elements that interact with one another. Child protection is an activity to guarantee and protect children and their rights so that they can live, grow, develop and participate, and receive protection from violence and discrimination. So what is meant by a legal protection system for child labor is a unit consisting of: a) Regulations of legislation as an element that regulates the interaction between child labor and employers and between employers 
and the government; b) in this case the Regional Office which handles manpower and existing law enforcement agencies, as an element that has the authority to enforce legal protection so that conflicts do not occur; c) child labor and employers / entrepreneurs as elements that always interact in the process of economic activities that can lead to conflict. first phase plan with a 5-year period, from the action plan ending in 2007, has 3 (three) main objectives: a) to increase public awareness about the forms of child labor required; $b$ ) mapping the worst forms of child labor; and c) to eliminate the worst forms of child labor in five sectors; children involved in selling and manufacturing and trading; children involved in the offshore fishing sector.

Harmonious relationships with parents make the child run away from the family and seek an outlet for his friends, is a very important factor for the child's psyche, when changes in household conditions such as divorce, so that makes the child experience a "broken home". Another factor in the family that can encourage children to become victims of trafficking for prostitution or prostitution is the application of discipline within the family itself. Compliance with parents is also a very important thing to be observed. The existence of disobedience to parents makes this child no longer pay attention to the advice or guidance from his parents, so that the child acts and behaves solely on the basis of his emotions alone. This makes the child trapped in a trade circle to be a prostitute, and this is never desired by the child.

\section{Barriers to Protection of Child Labor}

In 1989 Child Rights Convention expressly stated in Article 34 , the rights protection from sexual exploitation and abuse, including prostitution and involvement in pornography, but the protection of these children is always neglected, children due to physical immaturity require security and care specifically including proper legal protection before and after birth. The lack of legal protection provided to children trafficked for prostitution is not only done by law enforcement officials but the obstacles child protection also occur in the family and community. Families and communities should be able to exercise social control for the development of cases of child trafficking that occur. Actually, cases of child trafficking for prostitution are very large, but only a few cases can be monitored and handled. This is because these children who are victims of trafficking are reluctant to report law enforcement officials, making it difficult to resolve the case. The difficulties aside from the shame on the part of the victims themselves were also caused by the assumption of some people who said that an immoral case if disclosed would bring family disgrace, and it was this assumption that made the victims of this trafficking even more unwilling to report the incident they experienced. Children who are trafficked for prostitution purposes generally come from areas that are still undergoing a period of education and some are no longer continuing their education.

\section{CONCLUSION}

After analyzing data the following conclusions are derived: 1) Legal protection for children in Indonesia that the government and other state institutions are obliged and responsible to provide special children protection in emergency situations, children in conflict with the law, children and minority groups and isolated, children exploited economically and sexually, children who are victims of abuse of narcotics, alcohol, psychotropic, and other addictive substances (drugs), child abductees, sales, trafficking, children victims of violence both physical and / or mentally, a child who has a disability, and a child who is a victim of mistreatment and neglect; 2) legal protection of children as workers is the existence of other restrictions on employing children; in places where liquor is consumed and sold, in the place of handling public rubbish, 3) obstacles in the realization of legal protection against children as workers are cultural conditions in which children are the assets of parents.

\section{REFERENCES}

[1] Departemen Pendidikan dan Kebudayaan. 1999. Kamus Besar Bahasa Indonesia. Jakarta: Balai Pustaka.

[2] Gosita, A.1989. Masalah Perlindungan Anak. Jakarta :Akademi Pressindo.

[3] Gultom, M.2012. Perlindungan Hukum Terhadap Perempuan dan Anak. Bandung: Refika Aditama.

[4] Hadikusuma, H.1993. Hukum adat dalam yurisprudensi. Bandung: Citra Aditya Bakti

[5] Mappiare, A. 1982. Psikologi Remaja. Surabaya : Usaha Nasional.

[6] Setiardja, G. A. 1993. Hak-hak Asasi Manusia Berdasarkan Ideologi Pancasila. Yogyakarta: Universitas Negeri Jakarta

[7] Sumitro, S.1990. Aspek Hukum Perlindungan Anak. Jakarta: Bumi Aksara.

[8] Yuhassarie, E. 1999. Tinjauan Terhadap Penyelesaian sengketa Seri Dasar-Dasar Hukum Ekonomi Arbitase di Indonesia dalam Felox O Subagio. Jakarta : Cetakan Pertama April. 